\title{
NOTES
}

\section{CONSTITUTIONAT RIGHTS OF PRISONERS: THE DEVELOPING LAW}

\begin{abstract}
He [the convicted felon] has, as a consequence of his crime, not only forfeited his liberty, but all his personal rights except those which the lawe in its humanity accords to him. He is for the time being the slave of the State. ${ }^{1}$
\end{abstract}

This quotation illustrates what was once a typical judicial attitude toward the rights of prisoners. Today the analogy to slavery is being repudiated. A prisoner's rights are no longer considered exceptional privileges that the law "in its humanity accords him"; there is, instead, a growing recognition that "a prisoner retains all the rights of an ordinary citizen except those expressly, or by necessary implication, taken from him by law." 2 Acceptance of the fact that incarceration, because of inherent administrative problems, may necessitate the withdrawal of many rights and privileges, ${ }^{3}$ does not preclude recognition by the courts of a duty to protect the prisoner from unlawful and onerous treatment. ${ }^{4}$ Courts, at least in

1 Ruffin v. Commonwealth, 62 Va. (21 Gratt.) 790, 796 (1871).

2 Coffin v. Reichard, 143 F.2d 443, 445 (6th Cir. 1944).

3 See Price v. Johnston, 334 U.S. 266, 285 (1948) ; Davis v. Superior Court, 175 Cal. App. 2d 8, 20, 345 P.2d 513, 521 (Dist. Ct. App. 1959).

4 [I]t seems quite obvious that any further restraint in excess of that permitted by the judgment or constitutional guarantees should be subject to inquiry. An individual, once validly convicted ... . is not to be divested of all rights and unalterably abandoned and forgotten by the remainder of society. . . The State's right to detain a person is entitled to no greater application than its correlative duty to protect him from unlawful and onerous treatment ....

People ex rel. Brown v. Johnston, 9 N.Y.2d 482, 485, 174 N.E.2d 725, 726, 215 N.Y.S.2d 44, 45-46 (1961). See Davis v. Superior Court, $175 \mathrm{Cal}$. App. 2d 8, 345 P.2d 513 (Dist. Ct. App. 1959).

Crime cannot be punished by deprivation of federal citizenship. See Trop v. Dulles, 356 U.S. 86 (1958). However, this is possible as to state citizenship under civil death acts. See, e.g., CAI. PENAI CoDE $\$ \$ 2600-01$. See generally Comment, 26 So. Cal. L. Rev. 425 (1953); Note, 37 VA. L. Rev. 105 (1951); 34 VA. L. Rev. 463 (1948). Civil death statutes have been sustained as valid exercises of legislative power to prescribe punishment for crimes. E.g., Quick v. Western Ry., 207 Ala. 376, 92 So. 608 (1922). A sentence in a federal prison does not necessarily bring into operation the state civil death statute. See In the Matter of Anonymous, 12 Misc. 2d 1073 , 175 N.Y.S.2d 282 (Surr. Ct. 1958), modified, 17 Misc. 2d 691, 187 N.Y.S.2d 870 (Surr. Ct. 1959); O'Connor v. Cohen, 173 Misc. 419, 17 N.Y.S.2d 758 (Sup. Ct. 1940). The states may also impose reasonable restrictions on prisoners' exercise of federal rights during their incarceration in a state institution. See In re Ferguson, 55 Cal. $2 d$ 663, 361 P.2d 417, 12 Cal. Rptr. 753, cert. denied, 368 U.S. 864, 879 (1961). 
theory, have accepted the view that constitutional safeguards are intended to protect the rights of all citizens, including convicts.

The changing view of prisoners' rights brings two basic factors into conflict, and the effort to resolve this conflict has resulted in vagueness in the area of law determinative of prisoners' rights, the means of their assertion, and the remedies for their violation. The first factor is an understandable reluctance of the courts to interfere with prison management ${ }^{5}$ particularly in the case of federal courts and state prisons. ${ }^{6}$ All courts have recognized that prison officials must be given wide discretion to cope with the peculiar disciplinary problems with which they are inevitably faced. ${ }^{7}$ The second is the increasing repudiation by the courts of the idea that a prisoner is completely without any rights or remedies. The necessity-and difficulty-of reconciling these conflicting factors was well expressed in United States ex rel. Yaris $v$. Shanghnessy, ${ }^{8}$ where the court said: "It is hard to believe that persons . . . convicted of crime are at the mercy of the executive department and yet it is unthinkable that the judiciary should take over the operation of the . . . prisons. There must be some middle ground between these extremes. The courts have proceeded very slowly toward defining it." ${ }^{9}$ Courts, the decision continued, "will interfere if the treatment of prisoners amounts to [the] deprivation of [their] constitutional rights." 10 As examples the court pointed out that additional punishment may not validly be imposed upon a person convicted of murder, that prison regulations may not restrict the prisoner's right to apply for habeas corpus or prevent him from appealing his conviction, and that courts have at least considered prisoners' allegations of cruel and unusual punishment. ${ }^{11}$ However, a study of the cases involving alleged mistreatment indicates that the courts have been so influenced by the dogma of the independence of prison authorities that judicial intervention has been

5 See, e.g., Powell v. Hunter, 172 F.2d 330 (10th Cir. 1949); Fussa v. Taylor, 168 F. Supp. 302 (M.D. Pa. 1958) ; Peretz v. Humphrey, 86 F. Supp. 706 (M.D. Pa. 1949); Wright v. Wilkins, 26 Misc. 2d 1090,210 N.Y.S.2d 309 (Sup. Ct. 1961); Commonwealth ex rel. Smith v. Banmiller, 194 Pa. Super. 566, 168 A.2d 793 (1961).

6 See, e.g., Hatfield v. Bailleaux, 290 F.2d 632, 640 (9th Cir.), cert. denied, 368 U.S. 862 (1961) ; Oregon ex rel. Sherwood v. Gladden, 240 F.2d 910 (9th Cir. 1957) ; Ortega v. Ragen, 216 F.2d 561 (7th Cir. 1954), cert. denied, 349 U.S. 940 (1955).

7 See cases cited notes 5,6 supra. "[O]nly strict obedience to stern prison rules can possibly hold control over the eight thousand prisoners . . . many of whom are hardened, desperate, incorrigible criminals. Lax control . . . will inevitably lead to ... mutiny ... so as to endanger the lives of the prison officers and the maintenance of our prison system." O'Brien v. Olson, 42 Cal. App. 2d 449, 459, 109 P.2d 8, 15 (Dist. Ct. App. 1941). Prison authorities have the power to punish summarily infractions of prison regulations, since maintenance of discipline is an administrative rather than a judicial function. Thus, punishment by the prison authorities for violation of prison regulations concerning escape from prison does not bar a subsequent judicial action for the crime of escape on any theory of double jeopardy. See People v. Garmon, 177 Cal. App. 2d 301, 2 Cal. Rptr. 60 (Dist. Ct. App. 1960); State v. Williams, 57 Wash. 2d 231, 356 P.2d 99 (1960).

8112 F. Supp. 143 (S.D.N.Y. 1953).

9 Id. at 144 .

10 Ibid.

11 Ibid. 
limited to the extreme situation. Some courts have even stated the dogma in language which suggests that the courts have no jurisdiction over these matters. ${ }^{12}$ This last position is untenable if it is agreed that prisoners are guaranteed some rights; the duty to define and enforce the prisoner's rights and to balance, when necessary, these rights against the alleged demands of orderly prison administration is implicit in these guarantees. Until quite recently, this obligation was not met. ${ }^{13}$ Recent cases, ${ }^{14}$ however, indicate a willingness to strike such a balance and to attempt to search for the "middle ground" referred to in Shanghnessy.

In analyzing the rights of prisoners, the discussion logically breaks down into three areas: access to the courts, treatment while incarcerated, and remedies.

\section{ACcess to the Courts}

Unless the vindication of prisoner's rights is to be left to the discretion of the prison officials-which is tantamount to denying that such rights exist-the right on which all other rights for prisoners will turn is that of access to the courts. This includes both the right to communicate and those subsidiary rights which render communication effective.

\section{A. The Right to Communicate}

The courts have been readiest to interfere with prison administration when they have been called upon to protect access to the courts themselves. ${ }^{15}$ Most of the cases in this area involve efforts by the prisoner to challenge, either directly or collaterally, the validity of his conviction. Nevertheless, these cases are responsible for a weakening of the noninter-

12 In Feyerchak v. Hiatt, 7 F.R.D. 726 (M.D. Pa. 1948), the court, after denying that it had jurisdiction to grant petitioner the relief-characterized by the court as mandamus-requested, went on to say: "The problem ... is moreover one which involves administrative discretion ... which as an independent and abstract question is not within the jurisdiction of this Court." Id. at 728 .

13 In Eaton v. Bibb, 217 F.2d 446, 448 (7th Cir. 1954), cert. denied, 350 U.S. 915 (1955), the plaintiff complained, inter alia, that various prison rules and regulations deprived him of his constitutional rights. The court dismissed this issue without even examining the regulations involved merely by pointing out that federal courts do not have the power to regulate the ordinary internal management and discipline of state prisons. Accord, United States ex rel. Wagner v. Ragen, 213 F.2d 294 (7th Cir.), cert. denied, 348 U.S. 846 (1954); Morris v. Igoe, 209 F.2d 108 (7th Cir. 1953); United States ex rel. Morris v. Radio Station WENR, 209 F.2d 105 (7th Cir. 1953).

14 See, e.g., Pierce v. La Vallee, 293 F.2d 233 (2d Cir. 1961) ; Sewell v. Pegelow, 291 F.2d 196 (4th Cir. 1961) ; Bailleaux v. Holmes, 177 F. Supp. 361 (D. Ore. 1959), rev'd sib nom. Hatfield v. Bailleaux, 290 F.2d 632 (9th Cir.), cert. denied, 368 U.S. 862 (1961) ; Brown v. McGinnis, 10 N.Y.2d 531, 180 N.E.2d 791, 225 N.Y.S.2d 497 (1962).

15 See, e.g., Bailleaux v. Holmes, supra note 14; United States ex rel. Foley v. Ragen, 52 F. Supp. 265 (N.D. Ill. 1943), rev'd, 143 F.2d 774 (7th Cir. 1944); In re Robinson, 112 Cal. App. 2d 626, 246 P.2d 982 (Dist. Ct. App. 1952) ; Sweet v. State, 233 Ind. 160, 117 N.E.2d 745 (1954) ; In re Ferguson, 55 Cal. 2d 663, 361 P.2d 417, 12 Cal. Rptr. 753 (dictum), cert. denied, 368 U.S. 864 (1961). But see Siegel v. Ragen, 88 F. Supp. 996 (N.D. Ill. 1949), aff'd, 180 F.2d 785 (7th Cir.), cert. denied, 339 U.S. 990 (1950); In re Chessman, 44 Cal. $2 \mathrm{~d} 1,279$ P.2d 24 (1955). 
ference dootrine as a whole, both by establishing the first area in which courts talked of prisoner rights rather than privileges and by opening the door to the effective vindication of other prisoner rights as they were recognized.

In $E x$ parte $H u l l,^{16}$ a prison official refused to accept and mail the petitioner's habeas corpus petition. Despite this, the prisoner, with the aid of his father, was able to transmit to the court a document wherein he alleged, inter alia, this denial of access. The perennial problem of access cases-that when the prisoner reaches a court the allegations as to that prisoner are moot-apparently was not present here since the warden argued that this denial was justified by a prison regulation permitting censorship of such papers. This suggests that if the regulation were valid the petition might be dismissed as not properly before the court. However, the Supreme Court stated unequivocally that "the state and its officers may not abridge or impair petitioner's right to apply to a federal court for a writ of habeas corpus. Whether a petition for writ of habeas corpus addressed to a federal court is properly drawn and what allegations it must contain are questions for that court alone to determine." 17

The Court has also required that a state prisoner, discriminatorily deprived by prison authorities acting pursuant to prison rules of the opportunity to make a timely appeal to state courts, be heard or released. ${ }^{18}$ His continued confinement without the right of appeal generally given prisoners would be a violation of the fourteenth amendment. Although due process may not require the state to provide criminal appeals, ${ }^{19}$ when the state does so provide, arbitrary interference by prison authorities amounts to a denial of equal protection of the laws. ${ }^{20}$ Moreover, at least one state court has indicated that even reasonable institutional regulations may not be applied in such a manner as to limit the period in which the prisoner has the right to appeal. ${ }^{21}$

The guarantee of reasonable access can have no meaning unless the courts are willing to scrutinize the facts of each case to assure that this right has not been denied. Unless this is done, sentences might be indefinite, erroneous convictions never corrected, inhumane treatment never remedied. The existence of the writ of habeas corpus obviously requires a right of access. The question becomes: What rules may prison

16312 U.S. 546 (1941).

$17 I d$. at 549.

18 Dowd v. United States $e x$ rel. Cook, 340 U.S. 206 (1951); see Sweet v. State, 233 Ind. 160, 117 N.E.2d 745 (1954).

19 See Griffin v. Illinois, 351 U.S. 12, 18 (1956).

20 Dowd v. United States ex rel. Cook, 340 U.S. 206 (1951) ; Cochran v. Kansas, 316 U.S. 255 (1942); Sweet v. State, 233 Ind. 160, 117 N.E.2d 745 (1954); Ortega v. Ragen, 216 F.2d 561, 563 (7th Cir. 1954) (dictum), cert. denied, 349 U.S. 940 (1955); cf. Griffin v. Illinois, 351 U.S. 12 (1956).

21 People v. Howard, 166 Cal. App. 2d 638, 642, 334 P.2d 105, 108 (Dist. Ct. App. 1958). 
authorities promulgate without constitutionally infringing this right? 22 Only in extreme cases can this question be easily answered. For example, it would be unreasonable on its face and contrary to the spirit of Ex parte Hull to deny prisoners access to the courts unless they have managed to procure counsel. ${ }^{23}$

In the majority of cases the question will be closer and the guarantee of access must meet and overcome the noninterference doctrine which has had differing impacts upon judicial consideration of alleged direct denials of this right. ${ }^{24}$ Thus, when a petitioner alleged that he was denied the right to transmit a petition for habeas corpus because he failed to enclose the requisite number of copies of the petition, a Pennsylvania court denied relief since the action complained of was a matter of "internal management" with which it would not interfere. ${ }^{25}$ In contrast, a Maryland court, in dictum relying on $E x$ parte $H u l l$, declared that a petitioner has an absolute right to petition for habeas corpus and that it would be improper for the superintendent to refuse to forward a petition or to restrict its size or contents. ${ }^{26}$ Yet, despite differing degrees of amenability to prisoner petitions, in general the courts have shown an illiberal attitude in defining the right of access. For example, in Spires $v$. Dowd, ${ }^{27}$ the court held that the warden could not prevent the petitioner from mailing to the clerk of the proper state court any legal document addressed to that court. However, the court qualified its decision by pointing out that this right did not extend to the transmission of any materials directly to any judge, ${ }^{28}$ a privilege not constitutionally required. Moreover, although a petitioner may establish a denial of access to the courts, he may be denied relief be-

22 See Bailleaux v. Holmes, 177 F. Supp. 361 (D. Ore. 1959), rev'd sub nom. Hatfield v. Bailleaux, 290 F.2d 632 (9th Cir.), cert. denied, 368 U.S. 862 (1961).

23 White v. Ragen, 324 U.S. 760, 762 n.1 (1945); see United States ex rel. Foley v. Ragen, 52 F. Supp. 265 (N.D. IIl. 1943), rev'd, 143 F.2d 774 (7th Cir. 1944). The prisoner's decision to represent himself entitles him to no additional consideration in determining whether he has been accorded reasonable access.

24 See Hatfield v. Bailleaux, 290 F.2d 632, 641 (9th Cir.), cert. denied, 368 U.S. 862 (1961); Oregon ex rel. Sherwood v. Gladden, 240 F.2d 910, 912 (9th Cir. 1957); People v. Chessman, 38 Cal. 2d 166, 238 P.2d 1001 (1951), cert. denied, 343 U.S. 915 (1952). For example, he has no right to be present in court to argue his own appeal, Price v. Johnston, 334 U.S. 266, 284-85 (1948) ; Haines v. Castle, 226 F.2d 591, 594 (7th Cir. 1955), cert. denied, 350 U.S. 1014 (1956); People v. Chessman, 35 Cal. 2d $455,467,218$ P.2d 769, 776, cert. denied, 340 U.S. 840 (1950), although the federal courts have the power to issue an order in the nature of a writ of habeas corpus to permit this. Price v. Johnston, supra; Haines v. Castle, supra. In exercising their discretion whether or not to issue this order, the courts are to consider the best interests of both the prisoner and the Government. Theoretically, this is an opportunity for the court to ease the enormous burden that a prisoner must meet-especially a petitioner unrepresented by counsel-before judicial relief is possible.

25 Commonwealth ex rel. Sharp v. Day, 89 Pa. D. \& C. 605 (C. P. 1954); see Edmondson v. Warden, 194 Md. 707, 69 A.2d 919 (1949). The requirement in Sharp may well have been reasonable. The copies the prisoner was required to furnish were to go to various state offices: district attorney, attorney general, and possibly the parole board.

26 Warfield v. Raymond, $195 \mathrm{Md}$. 711, 713, 71 A.2d 870, 871 (1950).

27271 F.2d 659 (7th Cir. 1959).

28 Id. at 661. 
cause he chose an improper remedy or forum. ${ }^{29}$ Insofar as the gravamen of the petitioner's complaint is his difficulty in communicating with the court, such decisions, whatever their procedural justifications, reveal a particularly harsh attitude. Although they are not constitutionally required to do so, unless the courts are ready to overlook or correct such errors and guide the plea into proper channels, the prisoner must again begin his endeavors, difficult and perhaps doomed to failure, to reach the ear of the only authorities who can assure relief. ${ }^{30}$ These considerations are relevant whenever a prisoner is denied relief for what may be only pleading defects. In Siegal $v$. Ragen, ${ }^{31}$ the court held that even an allegation that the warden destroyed a petition for a writ of habeas corpus was insufficient to state a cause of action since the petitioner failed to set forth that it was his own petition and there was no constitutional right to prepare petitions of habeas corpus for other prisoners. ${ }^{32}$ To justify further its denial of relief the court neatly hoisted the petitioner by his own petard, saying:

[T] he fact that he was able to bring this action makes it highly improbable that he was prevented from filing his petition .... It is true, that in the past, certain prisoners were prevented from filing such petitions, but that situation has been remedied. At present, there are hundreds of petitions pending before the Court of this district. Consequently, there is ample grounds for this Court to take judicial notice that, as a general rule of practice, complete freedom to file petitions for zerits of habeas corpus is granted to the inmates of the State penitentiaries. ${ }^{33}$

Thus, this court was willing to take judicial notice that the allegations of petitioner were not true despite the fact that in the past prisoners had been denied the right to petition for habeas corpus. Clearly the fact that pris-

${ }^{29}$ E.g., Oregon ex rel. Sherwood v. Gladden, 240 F.2d 910 (9th Cir. 1957) ; United States ex rel. Atterbury v. Ragen, 237 F.2d 953 (7th Cir. 1956), cert. denied, 353 U.S. 964 (1957); United States ex rel. Foley v. Ragen, 143 F.2d 774 (7th Cir. 1944); Edmondson v. Warden, 194 Md. 707, 69 A.2d 919 (1949).

30 See text accompanying note 39 infra.

3188 F. Supp. 996 (N.D. I11. 1949), aff'd, 180 F.2d 785 (7th Cir.), cert. denied, 339 U.S. 990 (1950). Compare Ortega v. Ragen, 216 F.2d 561 (7th Cir. 1954), cert. denied, 349 U.S. 940 (1955), discussed in text accompanying note 42 infra.

3288 F. Supp. at 1000.

${ }^{33}$ Id. (Emphasis added.) Cf. United States ex rel. Foley v. Ragen, 143 F.2d 774 (7th Cir. 1944) (since prisoner was able to reach the federal district court there was no longer any bar to access and he should seek relief in the state courts). Compare Mar Gong v. Brownell, 209 F.2d 448 (9th Cir. 1954), involving a proceeding to establish United States citizenship. The district court judge had reasoned that, because of the discrepancies he had frequently found in the testimony of similar Chinese admission cases, the testimony of the case before him was probably without merit. Mar Gong v. McGranery, 109 F. Supp. 821 (S.D.N.Y. 1952). The inference thus raised against the plaintiff's credibility was rejected by the court of appeals: "It must be realized that this particular plaintiff may in fact be the lawful issue of a citizen father. However much fabrication or falsification the court may have found in its experience in the trial of other similar cases, we think it would be unjust to put what happened in those cases in the scale against this appellant." 209 F.2d at 453. 
oners' petitions are now reaching the court cannot, in the face of a history of obstruction, relieve the court of its obligation to examine the merits of each petition with care ${ }^{34}$ to make sure that any obstacles which may have been placed in the prisoner's path shall not be permitted in the future. Any doctrine of "judicial notice" in this area may help to render academic the prisoner's right to access to the courts.

The problem of mootness, discussed in connection with Ex Parte Hull and suggested by Siegel, presents the most serious conceptual barrier to a prisoner alleging denial of access. In People v. Superior Court the California Superior Court ordered that the petitioner be permitted to have immediate access by mail to the courts, to do all research necessary for the maintenance of his civil rights, to retain personal legal papers, and to consult privately with his counsel. The court's theory was that a denial of any one of these rights would constitute a denial of the right of access. The Supreme Court of California reversed on the ground that at the time of the hearing and the making of the order it did not appear that petitioner was presently being deprived of any rights. ${ }^{36}$ This argument, of course, could always be used to preclude any examination of an alleged denial of access. Thus the prisoner would find himself faced with the dilemma that if he fails to reach the courts he is obviously without hope of relief, while if he does he will be told that there is no longer a problem to be remedied. ${ }^{37}$ Justice Carter in dissent recognized the danger of accepting mootness as decisive in these cases and criticized the majority for its failure to realize that the prison authorities might again withhold these rights from the prisoner unless they were ordered otherwise. ${ }^{38}$ Without attempting to choose between the majority and the dissent on the merits it may be noted that Justice Carter made clear the considerations vital to the question's resolution. If there is a real danger that the petitioner will be denied his rights in the immediate future it should be of little significance that they are not presently being denied.

34 Compare the language in Haines v. Castle, 226 F.2d 591, 594 (7th Cir. 1955), cert. denied, 350 U.S. 1014 (1956) ("Undoubtedly, the repeated and persistent effort of certain inmates to have certain courts consider the validity of their detention in prison is annoying to prison officials and, in most cases is entirely unwarranted. However, the denial of the right to verify legal documents might, conceivably, in certain instances, be tantamount to a denial to a prisoner of the right to present his case to a court"), with Edmondson v. Warden, 194 Md. 707, 69 A.2d 919 (1949), in which the court in denying a writ of habeas corpus admitted that it was motivated by the number of times that the petitioner had previously applied to the courts.

35273 P.2d 936 (Cal. Dist. Ct. App. 1954).

36 In re Chessman, 44 Cal. 2d 1, 279 P.2d 24 (1955).

37 A slight variation of this problem involves the doctrine of exhaustion of remedies in habeas corpus proceedings. In United States ex rel. Foley v . Ragen, 143 F.2d 774,778 (7th Cir. 1944), the court of appeals reversed a district court, which had granted relief, on the theory that now that the ban on access to the courts was lifted the state courts were as accessible as the federal and therefore the petitioner should first have pursued his remedy there. Compare United States ex rel. Bongiorno v. Ragen, 54 F. Supp. 973 (N.D. I11. 1944), aff'd, 146 F.2d 349 (7th Cir. 1945), cert. denied, 325 Uं.S. 865 (1945).

$3844 \mathrm{Cal} .2 \mathrm{~d}$ at 10, 279 P.2d at 30 (dissenting opinion). 
Judicial protection of the rights of a prisoner would indeed be a mockery if the courts would always accept the pious protestations of the prison authorities that the rights would be accorded and then blithely disregard them the next day, leaving the prisoner to commence again his weary journey through the court process toward a chimerical goal. ${ }^{39}$

Once the mootness problem is overcome the court must decide how effective relief can be given and, insofar as the denial of access is the result of a general prison regulation, whether the relief is to be extended beyond the particular petitioners to all prisoners similarly situated. The techniques and the difficulties of relief are the same for both questions. The court can enjoin the objectionable conduct or regulation and hope that its admonition will prevent future interference although obviously the court may never learn if it is continued. In the final analysis, reliance may have to be placed on the efforts of third parties-district attorneys notified of the situation by the judge, various civil libertarian organizations, and the friends and relatives of prisoners.

\section{B. The Right to Prepare}

Closely related to the right to communicate with the courts is the right to have access to the materials needed to make this communication effective, although the courts have not shown the concern with its infringement that they have with respect to what may be termed direct denials of access. Although the free use of legal materials may lead some prisoners to the discovery that their substantive rights are being violated, and hence may be said to have a secondary substantive aspect itself, the right to prepare, like the right to communicate with the courts, is important primarily as an aid in remedying violation of other substantive rights.

Recognition that the prisoners' right to access to the courts is guaranteed by the fifth and fourteenth amendments has not been sufficient in itself to make this right effectively available. Although blatant interference is usually remedied by the courts, they have been particularly hesitant to interfere with more subtle methods of denying this right. Prior to the recent case of Bailleaux v. Holmes, ${ }^{40}$ the courts had never given serious consideration to the possibility that a denial of legal materials might preclude the meaningful exercise of this right. ${ }^{41}$ Thus, in Ortega $v$.

39 Id. at 12, 279 P.2d at 31.

40177 F. Supp. 361 (D. Ore. 1959), rev'd sub nom. Hatfield v. Bailleaux, 290 F.2d 632 (9th Cir.), cert. devied, 368 U.S. 862 (1961).

41 The view that a denial of legal materials and legal notes could constitute a denial of the right of access to the courts was accepted in one of the Chessman cases, People v. Superior Court, 273 P.2d 936 (Cal. Dist. Ct. App. 1954), but the decision was reversed by the California Supreme Court in In re Chessman, 44 Cal. 2d 1, 279 P.2d 24 (1955). The supreme court reasoned, inter alia, that Chessman was claiming "privileges," which prison authorities could properly deny, rather than rights. Id. at 10, 279 P.2d at 29. Accord, Grove v. Smyth, 169 F. Supp. 852 (E.D. Va. 1958); Piccoli v. Board of Trustees, 87 F. Supp. 672 (D.N.H. 1949). 
Ragen, ${ }^{42}$ the petitioner alleged that the warden refused to deliver a registered letter addressed to him containing material necessary for a pending court action, thereby preventing him from seeking relief from his unlawful confinement. Despite these allegations, the court held that petitioner failed to state a cause of action upon which relief could be granted. Starting with the premise that the mere withholding of a letter is an administrative matter not in itself violative of any federal rights, the court concluded that the petitioner's failure to allege the letter's contents made it impossible to determine if the refusal to deliver it actually interfered with any of his rights. This decision might be read as implying at least some right to legal materials. However, it reveals the same harsh attitude toward pleading defects shown by the courts with regard to alleged direct denials of the right to access, ${ }^{43}$ and the objections raised in that connection are equally relevant here.

In Oregon ex rel. Sherwood $v$. Gladden, ${ }^{44}$ even the implication that there might be a right to legal materials is absent. There the prisoner attempted to have the court determine the reasonableness of rules that, among other things, prohibited the petitioner from procuring such materials and information from other prisoners and from obtaining books from the Oregon State Library. The court refused to examine the validity of the regulations on the ground that it had no jurisdiction either to issue a writ of mandamus except in aid of its appellate jurisdiction, ${ }^{45}$ or, as a federal court, to supervise the administration of state penitentiaries. ${ }^{46}$ Even if the decision is read as only denying the remedy and not the right, it is unacceptable. It seems that there should be a right-and of necessity a remedy-to engage in legal research which is intimately connected with a prisoner's access to the courts-especially when the prisoner is unable to procure counsel. ${ }^{47}$ There appears to be no justification for limiting the constitutional right of prisoner access to the courts to the presentation of facts rather than legal propositions. If the transmission of legal arguments is included, how can the right be meaningful unless the courts assure prisoners reasonable access to law books and legal materials? Although neither the states nor the federal government may be obligated to provide law libraries for their inmates or to permit them to convert their cells into libraries, some opportunity of access to such materials should be deemed an integral part of access to the courts. Unless such a right exists, the

42216 F.2d 561 (7th Cir. 1954), cert. denied, 349 U.S. 940 (1955).

43 See text accompanying note 30 supra.

44240 F.2d 910 (9th Cir. 1957).

$45 I d$. at 911.

46 Ibid. The court did indicate, however, that if instead the petitioner applied for a writ of habeas corpus, the district court might consider whether the conduct of the authorities was such as to make petitioner's resort to state remedies impossible, thus permitting a federal court to assume jurisdiction. Ibid.

47 See Bailleaux v. Holmes, 177 F. Supp: 361 (D. Ore. 1959), rev'd sub nom. Hatfield v. Bailleaux, 290 F.2d 632 (9th Cir.), cert. denied, 368 U.S. 862 (1961); In re Chessman, 44 Cal. $2 \mathrm{~d} 1,13-15,279$ P.2d 24, 31 (1955) (dissenting opinion). 
prisoner may be unable to discover that other rights have been infringed. Even if he does know this, he may, without the aid of legal materials, be unable to present his complaint effectively even though he is able to reach the courts. To make clear the existence of these rights, the courts might adopt as general propositions that where such materials are available within the prison, access to them must be nondiscriminatory, that prisoners must be permitted to obtain these materials for themselves, and that any limitation on the exercise of these rights must be justified by the prison authorities.

There are indications that the noninterference doctrine is breaking down-or at least being questioned-in this area. The first step in this direction has been the requirement on the part of a few courts that rules which may interfere with the prisoner's exercise of his constitutional rights must be reasonable. Bailleaux $v$. Holmes 48 is an example of an attempt to apply this new view. Several inmates of the Oregon state penitentiary brought an action under the Civil Rights Act ${ }^{49}$ seeking to enjoin the enforcement of certain prison regulations that allegedly interfered with their right to have effective access to the courts. The regulations in question limited the time and places in which legal work could be done and restricted the acquisition and retention of law books and other legal materials. Each of the petitioners alleged that he had to do his own legal work because he could not afford to engage an attorney. The petitioners successfully contended in the district court ${ }^{50}$ that the totality of these regulations had the effect of denying them the reasonable access to the courts guaranteed to them by the fourteenth amendment. The court enjoined the prison authorities from prohibiting petitioners, if not in isolation, from using their free cell-time for the purpose of studying law and preparing legal documents or, if in isolation, from communicating with counsel and having reasonable opportunity to prepare their legal work-taking due regard of the purpose of isolation; from preventing the purchase of legal materials; and from confiscating legal documents for violation of prison regulations. The district court appreciated the "fact that prison authorities must maintain effective discipline . . . However, this end could not be achieved by stifling the study of law, where such study is necessary to the effective utilization of a basic right." 51 The court of appeals, while accepting the principle that the fourteenth amendment guaranteed reasonable access to the courts, reexamined the merits of the case and found it "self evident" that the petitioners did have reasonable access. ${ }^{52}$ As to the general prison population, the court concluded that the regulations were for the purpose

48177 F. Supp. 361 (D. Ore. 1959), rev'd sub nom. Hatfield v. Bailleaux, 290 F.2d 632 (9th Cir.), cert. denied, 368 U.S. 862 (1961).

49 Rev. Stat. §1979 (1875), 42 U.S.C. $\$ 1983$ (1958).

50 Bailleaux v. Holmes, 177 F. Supp. 361 (D. Ore. 1959), 58 Mich. L. Rev. 1233 (1960), 39 TeXas L. Rev. 228 (1960).

51177 F.2d at 361.

52 Hatfield v. Bailleaux, 290 F.2d 632, 640 (9th Cir. 1961). 
of discouraging "cell-house lawyers" and not to hamper inmates in gaining reasonable access to the courts. As for the prisoners in isolation, the court concluded that the period of isolation was of a short duration so that it was reasonable to deny prisoners their right to communicate with their attorneys or to have any access to legal papers. The appellate opinion is open to criticism for its willingness to justify a restriction of access to legal materials on which prisoner rights depend by a fear of "cell-block" lawyers; general deprivation of all prisoners should not be based on the danger that certain of their number might become a nuisance. And the danger of an increase in the number of groundless legal complaints is primarily a concern of the courts, which would be the real victims of the increase and are the proper bodies to determine the legal sufficiency of complaints. ${ }^{53}$ Moreover, although it is not unlikely that many particular regulations could be sustained as reasonable restrictions on the rights of prisoners, it seems clear that prisoner access to the courts becomes meaningful only when access to legal materials is protected and that this protection, in turn, takes on substance only when the courts are willing to look into the specifics of the situation, as did the district court in Bailleaux, which refused to dismiss the petition on the basis of vague generalities..$^{54}$

\section{Treatment During Incarceration}

Although access to the courts is important in that it permits prisoners to appeal or attack collaterally their original convictions, it has taken on additional significance by allowing prisoners to seek redress for improper treatment during imprisonment. This is true not only in the direct sense that it has permitted prisoners to raise questions of mistreatment before the courts but also in that the reexamination of the noninterference doctrine in the area of access to courts has carried over to a degree into the considerations of treatment during incarceration. Nevertheless, the area remains shadowy because of the comparative paucity of cases, and delineation is severely hindered by the continuing influence of the noninterference doctrine.

In examining the rights of prisoners to be free from unlawful and inhumane treatment, two questions must be answered with respect to each possible "right." First, can the prisoner claim a right to be treated in a specific way, or only a privilege? And second, even if the treatment is only

53 See text accompanying note 17 supra.

54 Another way in which a prisoner may be indirectly denied reasonable access to the courts is by interference with his efforts to consult privately with counsel. Although this right has been recognized by the courts only with respect to prisoners held pending trial, see In re Rider, 50 Cal. App. 797, 195 Pac. 965 (Dist. Ct. App. 1920), a prisoner who is trying to appeal his conviction or is alleging a denial of some constitutionally protected right seems to have the same need for such private consultation, see Kahn v. La Vallee, 12 App. Div. 2d 832, 209 N.Y.S.2d 591 (1961) (dictum). On the other hand, reasonable interference in this area might be necessary either to prevent possible violence or to make disciplinary measures such as isolation effective. 
a privilege, does the prisoner still have a right to enjoy it in a nondiscriminatory manner?

\section{A. Censorship and Use of the Mails}

There is no doubt that prison authorities have the right to examine and, to some extent, censor all mail that is not addressed to the courts. 55 For the most part, courts have avoided consideration of any alleged arbitrary interference with prisoners' rights in this area simply by stating in unqualified terms that there is no constitutionally protected right for prisoners to use the mails. ${ }^{56}$ Some cases, however, seem to suggest that an absolute ban on all communication would be constitutionally unreasonable..$^{57}$ And it seems clear that even if a denial of the use of the mails is not a constitutional problem itself, it becomes one where the rule is applied in an arbitrary or discriminatory manner. ${ }^{58}$ Accordingly, there is at least a minimum obligation on the courts to determine if the regulation in question is improperly being applied to the detriment of a particular prisoner or class of prisoners.

The courts have not yet been presented with the challenge of meeting this obligation. Restrictions imposed by prison authorities on prisoners' use of the mails have generally appeared to be reasonable. For example, it does not appear constitutionally arbitrary for authorities to prevent prisoners from writing letters "romantic in nature," 59 to refuse to permit prisoners to draw up patents and send them to the federal government ${ }^{60}$ or to continue correspondence courses, ${ }^{61}$ or to prevent correspondence with the daughter of the superintendent of another institution on the ground that the prisoner had delusions regarding the girl. ${ }^{22}$ However, there is a danger in an unquestioning acceptance by the courts of these apparently valid administrative measures in the name of noninterference. A pattern of review has developed wherein the courts have refused to probe beneath the surface of these regulations to the manner and effect of their application.

55 E.g., Ortega v. Ragen, 216 F.2d 561 (7th Cir. 1954), cert. dertied, 349 U.S. 940 (1955); Adams v. Ellis, 197 F.2d 483 (5th Cir. 1952); United States ext rel. Vraniak v. Randolph, 161 F. Supp. 553 (E.D. I11.), aff'd, 261 F.2d 234 (7th Cir. 1958), cert. denied, 359 U.S. 949 (1959) ; Green v. Maine, 113 F. Supp. 253 (D. Me. 1953), modified sib nom. Green v. Robbins, 120 F. Supp. 61 (D. Me. 1954), aff'd, 218 F.2d 192 (1st Cir. 1954). As to censorship of mail addressed to the courts, see notes 15-21 supra and accompanying text.

56 E.g., Ortega v. Ragen, supra note 55, at 562; United States ex rel. Vraniak v. Randolph, supra note 55 , at 560 ; Green v. Maine, supra note 55 , at 256 .

${ }^{57}$ See Dayton v. McGranery, 201 F.2d 711, 712-13 (D.C. Cir. 1953) ; cf. Davis v. Superior Court, 175 Cal. App. 2d 8, 345 P.2d 513 (Dist. Ct. App. 1959).

58 In Dayton v. McGranery, supra note 57, the court recognized that mail rights may not be arbitrarily denied but decided, without really examining the merits of the complaint, that there was no arbitrary denial.

59 Dayton v. Hunter, 176 F.2d 108 (10th Cir.), cert. denied, 338 U.S. 888 (1949); see Fussa v. Taylor, 168 F. Supp. 302 (M.D. Pa. 1958).

${ }^{60}$ United States ex rel. Wagner v. Ragen, 213 F.2d 294 (7th Cir.) (alternate holding), cert. denied, 348 U.S. 846 (1954).

61 Numer v. Miller, 165 F.2d 986 (9th Cir. 1948).

62 Dayton v. McGranery, 201 F.2d 711 (D.C. Cir. 1953). 
Numer v. Miller ${ }^{63}$ provides an example of the limitations which may be placed on a prisoner's use of the mails. The petitioner alleged that he had been denied access to educational facilities afforded all other inmates in that the prison authorities refused to permit him to continue a correspondence course in which he had originally been given permission to enroll. The refusal came after petitioner explained that his purpose for taking the course was that upon his release he intended to write an exposé of the prison authorities, whom he described as "a sadistic group in charge of the brutality department." ${ }^{64}$ The court of appeals denied that the case might be cognizable by the district court, pointing out that Congress entrusted the discipline of federal penitentiaries to the Bureau of Prisons. ${ }^{65}$ The court then disposed of the possibility of any constitutional infringement of the prisoner's rights: "[A]s to the asserted violation of constitutional guaranties we may add that a prisoner who persists in abusing $a$ privilege . . . is in no position to complain of unequal treatment if that privilege is taken away from him." 06 By speaking in terms of "privilege" the court obscured the fact that a prisoner has the right to be treated like other prisoners similarly situated. Recognition of this fact would seem at least to require the court to decide the question of whether or not it was constitutionally permissible for a prisoner to be denied rights granted others merely because of his intention to write, upon release, a book criticizing the prison authorities.

Again, although there exists no absolute right to use the mails, it would seem that a total bar applied to all prisoners would be constitutionally unjustifiable. It is unlikely, of course, that any such blanket restriction would be attempted and so the question before the courts will go to the permissibility of restrictions directed at individual prisoners, or limitations on access directed to the prison population as a whole. In these situations an examination of the nature of the restriction and its proferred justification must be made if there is to be any judicial definition of the extent of the right. Such an examination and resolution is not likely to be made in view of the pattern of summary disposal of such allegations.

\section{B. Discrimination Because of Race or Religion}

\section{The Nondiscriminatory Practice of Religion}

Although no court has apparently ever questioned the right of a prisoner to his religious beliefs, restrictions upon the practice of that faith have

63165 F.2d 986 (9th Cir. 1948).

64 Ibid. Clearly if this was a letter to the courts such language would not justify censoring the letter, or preventing its transmission. See In re Ferguson, $55 \mathrm{Cal}$. 2d $663,675-76,361$ P.2d 417, 424-25, 12 Cal. Rptr. 753, 760-61, cert. denied, 368 U.S. 864 (1961).

65 Numer v. Miller, 165 F.2d 986, 986-87 (9th Cir. 1948).

68 Id. at 987. (Emphasis added.) 
been judicially accepted. Here again the cases have generally involved the issue of discriminatory restrictions upon the enjoyment of religious freedom rather than any complete interdiction. This is an area in which the dogma of noninterference appears to be waning. Increasingly courts-perhaps sensitive because of the "preferred" position of these rights ${ }^{67}$-have proved unwilling to permit denials of freedom of religion even when placed on the ground of administrative control of prison discipline which has generally been held to justify denial of "lesser" rights.

The clearest indication of this attitude is found in McBride v. McCorkle, ${ }^{68}$ in which the court clearly recognized that prisoners retained an affirmative right of freedom of religious practice-although it was held that this right could not be absolute for prisoners any more than it could be for free men. In this case, inmates who were in segregation alleged a denial of the free exercise of their religion in the authorities' refusal to permit them to attend Mass on Sundays and holy days as prescribed by the Roman Catholic Church. Although the inmates in segregation were not permitted to accompany the general prison population to the chapel, chaplains of each religious faith were permitted to visit the prisoners in their cells for religious guidance. The Catholic chaplain, however, refused to say Mass in the segregation wing which had no chapel. Starting from the basic proposition that religious freedoms could be denied only if the court found that the restrictions were reasonably necessary to protect some paramount societal interest, ${ }^{69}$ the New Jersey court closely examined the merits of the petitioners' complaint. The court pointed out that this treatment of the petitioners was a function of their position within the prison rather than of their faith and, therefore, was not discriminatory. Furthermore, the petitioners were given the opportunity to receive the sacraments through visits of Catholic chaplains. The court therefore concluded that it was permissible for the prison authorities to decide that it would impair the disciplinary effect of continuous segregation if the petitioners were permitted to attend Mass with the general prison population. Accordingly, the regulations in question were held to involve no unwarranted restriction upon the prisoners' freedom of religion. ${ }^{70}$

Kelly v. Dozed ${ }^{71}$ illustrates, on the other hand, the courts' traditional reluctance to interfere even in this area. There, the court of appeals affirmed the dismissal of a petition for an injunction which would have ordered the warden to grant the petitioner the right to receive bible-study help from an established religion. But, although the opinion did not show the careful consideration of prisoners' rights to religious freedom which

67 See, e.g., Pierce v. La Vallee, 293 F.2d 233, 235 (2d Cir. 1961).

6844 N.J. Super. 468, 130 A.2d 881 (App. Div. 1957).

$69 \mathrm{Id}$. at $479,130 \mathrm{~A} .2 \mathrm{~d}$ at $886-87$.

$70 \mathrm{Id}$. at $480,130 \mathrm{~A} .2 \mathrm{~d}$ at 887 . It is perhaps ironic that at the time of suit the prison authorities were building a chapel in the segregation wing. Ibid.

71140 F.2d 81 (7th Cir.), cert. denied, 321 U.S. 783 (1944). 
may be seen in the McBride opinion, this difference may be justified both by the fact that in Kelly a federal court was being asked to examine the conduct of state officials without any attempt to raise the question in the state courts ${ }^{72}$ and by the failure of the petitioner to allege that he had ever requested permission to receive the literature in question. ${ }^{\mathbf{7 3}}$

Perhaps the major catalyst in the recent shift in judicial attitude has been the new religious group commonly known as the "Black Muslims." Thus, the New York Court of Appeals, in Brown v. McGinnis, ${ }^{74}$ in the course of holding that the petitioner could compel the prison authorities to permit him free exercise of his religion, subject to reasonable rules and regulations, spoke in strong language concerning the right of prisoners to the freedom of religion ${ }^{75}$ and stressed the fact that restrictions on the practice of religion must be based upon a showing of danger and not mere speculation. ${ }^{78}$

A different attitude may be seen in In re Ferguson, ${ }^{77}$ which involved an examination by the California Supreme Court of restrictions placed upon the religious activities of this group. Muslim literature, characterized by the correctional officer as "trash," 78 had been confiscated, and the Muslims were admittedly not granted the same rights as recognized religious groups. Specifically, the petitioners alleged that they were not allowed a place to worship, that their religious meetings were broken up, that they were not allowed to possess an adequate amount of their religious literature, and that their religious leaders were not allowed to visit them in prison. The warden admitted the discriminatory treatment, but argued that it was justified since the petitioners' principles interfered with orderly prison management. This argument persuaded the court that "even conceding the Muslins to be a religious group it can not be said under the circumstances here presented that the Director of Corrections has made an unreasonable determination in refusing to allow petitioners the opportunity to pursue their claimed religious activities while in prison." 79 Despite its arguendo aside, the court seemed to have been influenced by the belief that the "Black Muslims" were not a religious group-the Director of Corrections, had, in fact, denied them this classification ${ }^{80}$-entitled to any of the protections enjoyed by such groups. This belief seems to have been used to justify the unhesitating denial of a requested order for the return

72 Id. at 83.

73 Id. at 82-83.

7410 N.Y.2d 531, 180 N.E.2d 791, 225 N.Y.S.2d 497 (1962).

75 Id. at 534-36, 180 N.E.2d at 792-93, 225 N.Y.S.2d at 499-500.

76 Id. at 536, 180 N.E.2d at 793, 225 N.Y.S.2d at 500.

7755 Cal. $2 \mathrm{~d}$ 663, 361 P.2d 417, 12 Cal. Rptr. 753, cert. denied, 368 U.S. 864 (1961), Comment, 35 So. CaL. L. REv. 162 (1962).

78 Id. at 668,361 P.2d at 419,12 Cal. Rptr. at 755.

$79 \mathrm{Id}$. at $672,361 \mathrm{P} .2 \mathrm{~d}$ at $421,12 \mathrm{Cal}$. Rptr. at 757. (Emphasis added.)

80 Id. at 667,361 P.2d at 418,12 Cal. Rptr. at 754 . 
of a confiscated religious scrapbook which the court considered "as an ordinary writing advocating or encouraging prohibited conduct" 81 and to permit the court to refuse to order the prison authorities to allow the petitioners to purchase their scriptures, a version of the Koran. ${ }^{82}$ Insofar as the decision relies on a tacit determination that the Muslims are not a religion, it conflicts with other recent cases involving this group, ${ }^{83}$ which have acknowledged that the claim to first amendment protection is substantial enough to require a hearing. And if, upon hearing, it is recognized that the Muslims are a religious sect, it becomes incumbent upon the court to require that the Muslims be accorded the same opportunities as other faiths to practice their religion to the extent that this is possible without significantly disturbing prison discipline. ${ }^{84}$ Thus, the proper disposal of the petition would have been to permit the petitioners to have obtained at least all religious materials which were not "inflammatory" in nature. There appears to be no justification for the court deciding quite broadly that there can be no right to assemble and discuss any of the Muslim doctrines merely because one of the Muslim principles happens to be the inevitability of "black supremacy." In the past freedom of religion has been jealously protected in the face of many conflicting and persuasive values. ${ }^{85}$ If Black Muslimism is a religion, its exercise demands judicial protection to the extent consistent with prison discipline. Because it is new, "odd," and the vehicle of minority aspiration it is imperative that the courts subject the actions of prison authorities with respect to the Muslims to the closest possible scrutiny.

$M c B r i d e$, rather than Ferguson, represents the attitude which appears to be the more widely accepted today. In Servell v. Pegelowe, ${ }^{86}$ the Black Muslim petitioners alleged that the prison authorities had deprived them, solely because of their religious beliefs, of certain constitutional and statutory rights going to both the practice of their religion and the enjoyment of privileges accorded other prisoners. Thus the complaint presented three

81 Id. at 674,361 P.2d at 423,12 Cal. Rptr. at 759.

82 Ibid. The Muslim Koran did not appear to be the standard Mohammedan scriptures. The New York State Director of Corrections recently ordered that inmates were to be permitted to purchase certain translations of the Koran. Pierce v. La Vallee, 293 F.2d 233, 236 (2d Cir. 1961).

83 See Pierce v. La Vallee, 293 F.2d 233 (2d Cir. 1961) ; Sewell v. Pagelow, 291 F.2d 196 (4th Cir. 1961).

84 This in fact was the position of the petitioners. See Brief for Appellants, p. 4, In re Ferguson, 55 Cal. $2 \mathrm{~d} 663,361$ P.2d 417, 12 Cal. Rptr. 753, cert. denied, 368 U.S. 864 (1961). It should be recognized that undoubtedly many of the Muslim doctrines are disturbing to the white prison authorities. The Muslims identify white persons with "evil" and blame the subjected condition of the Negro to the conspiracy of the whites who in the past have colonized, enslaved, exploited, despised, lynched, and disenfranchised the black people. Id. at 8.

${ }^{85}$ E.g., West Va. State Bd. of Educ. v. Barnette, 319 U.S. 624 (1943) ; Cantwell v. Connecticut, 319 U.S. 296 (1940); see Trescher \& O'Neill, Medical Care For Dependent Children: Manslanghter Liability of the Christian Scientists, 109 U. PA.

L. Rev. 203 (1960); Comment, 26 U. CHI. L. Rev. 471 (1959).

86291 F.2d 196 (4th Cir. 1961). 
questions of constitutional significance: interference with the practice of religion; discrimination in the practice of religion; and discrimination on the basis of religion-or if Black Muslimism should, on remand, not be found to be a religion, on the basis of a possible arbitrary classification. Nevertheless, the district court, without even holding a hearing or waiting for an answer, dismissed the complaint on the theory that since the matter involved the internal discipline of the reformatory it was without jurisdiction to entertain the complaint. The appellate court, however, reversed, pointing out that this was more than an attack upon disciplinary measures taken by the prison authorities. Rather the case involved hardships allegedly inflicted for no other reason than that these authorities viewed the appellants' religion unfavorably. The court found the case "manifestly unlike those in which the courts have declined to interfere because particular disciplinary measures were taken within the normal management of the institution." 87 Although the court found it unnecessary at that time to adjudicate the extent of the prisoners' rights, by requiring a hearing on the allegations it implicitly acknowledged the merits of the McBride approach. ${ }^{88}$

\section{Racial Discrimination}

While some of the cases previously discussed may have involved what amounted to racial as well as religious discrimination, the petitioners chose to emphasize the religious issue. ${ }^{89}$ In Nichols $v . \mathrm{McGee}^{90}$ and United States ex rel. Morris v. Radio Station WENR, ${ }^{01}$ the federal courts had an opportunity to deal specifically with the issue of racial discrimination. In Morris the petitioner alleged that the prison authorities discriminated by denying Negroes the opportunity to audition or act as announcers for the radio program that the authorities had established. The court of appeals

87 Id. at 197.

88 See also Pierce v. La Vallee, 293 F.2d 233 (2d Cir. 1961) ; Brown v. McGinnis, 10 N.Y.2d 531, 180 N.E.2d 791, 225 N.Y.S.2d 497 (1962). The Pierce court rejected the requirement that a state prisoner must first seek his relief in a state forum, treating it as a traditional procedural barrier. Significantly, however, the cases distinguished and disapproved by the court, unlike the case before it, did not involve suits under the Civil Rights Act. E.g., Oregon ex rel. Sherwood v. Gladden, 240 F.2d 910 (9th Cir. 1957) (mandamus); Kelly v. Dowd, 140 F.2d 81 (7th Cir.), cert. denied, 321 U.S. 783 (1944) (habeas corpus) ; Piccoli v. Board of Trustees, 87 F. Supp. 672 (D.N.H. 1949) (injunction). The exhaustion doctrine has never been an impediment to suits under the Civil Rights Act, e.g., Hatfield v. Bailleaux, 290 F.2d 632 (9th Cir.), cert. denied, 368 U.S. 862 (1961), although in the areas of habeas corpus and injunctive relief it has been firmly established. Accordingly, despite the strength of the court's rejection the decision should have no effect on other remedial devices. However, this fact does not detract from the decision's importance in clearly illustrating the growing tendency of the courts to overlook the noninterference dogma.

89 See Brief for Petitioners, pp. 1-3, In re Ferguson, 55 Cal. 2d 663, 361 P.2d 417, 12 Cal. Rptr. 753, cert. denied, 368 U.S. 864, 879 (1961). 245.

90169 F. Supp. 721 (N.D. Cal.), appeal dismissed, 361 U.S. 6 (1959), 36 DICTA

91209 F.2d 105 (7th Cir. 1953). 
found it to be "clearly evident" that the complaint was entirely without merit.92 Without even considering the truth of the allegations of discrimination the court justified its decision by reference to twin dogmas: first, that, in any case, prison discipline is not a function of the federal courts, and, secondly, that federal courts rarely interfered with state officials in the performance of their duties. ${ }^{93}$ The court made its position clear by stating that "a prisoner may not approve of prison rules and regulations, but under all ordinary circumstances that is no basis for coming into a federal court seeking relief even though he may clain that the restrictions placed upon his activities are in violation of his constitutional rights." ${ }^{94}$ In light of the petitioner's allegations that it was impossible to obtain relief in the state courts, this language can only mean that this petitioner's constitutional rights could not be protected; the court did not explain what would be the extraordinary circumstances which would justify relief. This view, clearly not in harmony with the more recent decisions dealing with alleged denials of religious freedom, ${ }^{95}$ was reiterated in Nichols v. McGee. ${ }^{96}$ There an inmate of the California State Prison sought to convene a three-judge court to examine his allegation of racial discrimination. The petitioner alleged, inter alia, that he was kept in an exclusively Negro cell and was required to eat in a walled-off Negro compartment in the dining hall. In addition, there was an allegation that the Negro dining facilities were unequal since they were located furthest from the available exit and would be dangerous in the event of fire or disorder. ${ }^{97}$ The theory of the petitioner was that such racial segregation caused a loss of self-respect and was prohibited by Brown $v$. Board of Educ. ${ }^{98}$ The court found three reasons why the petitioner's complaint should not be heard. First, inasmuch as petitioner sought to question the constitutionality of a departmental regulation or policy rather than a statute, the issue could not properly be brought before a three-judge court. ${ }^{99}$ The court also concluded that a fatal defect in the complaint was the failure to show that his rights could not be preserved by a proper proceeding in the state courts. Finally, the court concluded that "even if recourse had first been had to the courts of California, plaintiff's proposed complaint could state no cause of action in this Court." 100 This last reason is the most

92 Id. at 107. The petitioner had been careful to allege that he had been unable to obtain a hearing in any state court.

93 Ibid.

94 Id. (Emphasis added.)

95 See notes 67-88 supra and accompanying text.

96169 F. Supp. 721 (N.D. Cal.), appeal dismissed, 361 U.S. 6 (1959).

97 Id. at 723.

98347 U.S. 483 (1954).

99 But cf. Lathrop v. Donohue, 367 U.S. 820, 824-27 (1961).

100 Nichols v. McGee, 169 F. Supp. 721, 724 (N.D. Cal.), appeal dismissed, 361 U.S. 6 (1959). 
significant in terms of potential barriers to recognition of the civil liberties of prisoners. The court's position was that not all infringements of the constitutional rights of prisoners would justify judicial intervention but only interferences so "grave" and "substantial" and reaching "such a constitutional magnitude" as would justify departure from the general rule of noninterference.101 However this test may be construed in the future, this court indicated that "ordinary" discrimination based solely on the race of the individual does not fall within its proscription. Moreover, the court's blanket determination that "by no parity of reasoning can the rationale of Brown v. Board of Education . . . be extended to State penal institutions" ${ }^{102}$ seems unwarranted. ${ }^{103}$

\section{Physical Mistreatment}

The eighth amendment specifically prohibits cruel and unusual punishment; ${ }^{104}$ and either this prohibition or a similar one is extended to the states by the due process clause of the fourteenth. ${ }^{105}$ The problem lies in determining what conduct falls within the constitutional command whose scope has had only the vaguest delineation provided by a relative handful of decisions limited to some particular mistreatment. ${ }^{106}$ A review of these cases makes clear only the unlikelihood of a petitioner's assertion of mistreatment. The problem in this area is not that the right to be free from inhumane treatment is not recognized but rather the difficulty of substantiating the complaint. This is due partially to the court's traditional

$101 \mathrm{Id}$. at 725.

102 Id. at 724 .

103 Insofar as socio-psychological insights support Brozen, they are clearly not limited to the facts of that case, and the demands of the equal protection clause have been extended beyond the area of education. See, e.g., Moorhead v. City of Fort Lauderdale, 152 F. Supp. 131 (S.D. Fla.), aff'd, 248 F.2d 544 (5th Cir. 1957) (recreational facilities); Browder v. Gayle, 142 F. Supp. 707 (M.D. Ala.), aff'd per curiam, 352 U.S. 903 (1956) (buses). Although the danger of violence, for example, might justify temporary or partial segregation, it seems that even this must be limited to extreme cases. See Cooper v. Aaron, 358 U.S. 1 (1958).

104 See, e.g. Commonwealth ex rel. Smith v. Banmiller, $194 \mathrm{~Pa}$. Super. 566, 168 A.2d 793 (1961); United States ex rel. Atterbury v. Ragen, 237 F.2d 953, 958 (7th Cir. 1956) (concurring opinion), cert. denied, 353 U.S. 964 (1957); Sutherland, Due Process and Cruel Punishment, 64 Harv. L. Rev. 271 (1950); Note, 1960 WasH. U.L.Q. 160 n. 4.

105 See Louisiana ex rel. Francis v. Resweber, 329 U.S. 459 (1947); id. at 466 (Frankfurter, J., concurring). Moreover, many states have constitutional provisions prohibiting cruel and unusual punishments. E.g., CAL. CoNst. art. I, $\$ 6 ;$ N.Y. CoNsT. art. I, § 5 .

106 For example, Congress could not take away citizenship as punishment for wartime desertions, Trop v. Dulles, 356 U.S. 86 (1957); a second attempt at execution was not cruel and unusual punishment, Louisiana ex rel. Francis v. Resweber, 329 U.S. 459 (1947); a statute requiring a vasectomy operation on those twice convicted of a felony violated due process, Davis v. Berry, 216 F.2d 413 (S.D. Iowa 1914) rev'd on other grounds, 242 U.S. 468 (1917); keeping prisoners in a prison described as a "fabulous obscenity" by health officials did not amount to cruel and unusual punishment, Ex parte Pickens, 101 F. Supp. 285 (D. Alaska 1951). 
reluctance to supervise the administration of prisons. ${ }^{107}$ Another significant factor, however, is the enormous evidentiary burden of proving mistreatment. The existence of prisoner rights provides small solace unless they can be translated into reality. But there are inherent in the prison situation difficulties which are likely to prove insurmountable. Cases involving alleged mistreatment are likely to turn, even assuming good faith, on disputed issues of fact. In the resolution of these disputes not only are the authorities likely to have control over all the available evidence, ${ }^{108}$ but their testimony will probably carry more weight than that of the prisoner. ${ }^{100}$ This problem of discrediting the prisoner's testimony is also present with respect to the testimony of other prisoners who may be the only witnesses, even assuming they are willing to risk possible retribution, the prisoner can obtain. ${ }^{110}$ Despite the understandable unwillingness of courts to waste time on apparently frivolous claims, the difficulties facing a prisoner who seeks to prove that he has been subject to unconstitutional treatment suggest that the courts should undertake to ensure that petitioners have every possible opportunity to substantiate their claims. ${ }^{111}$

It may be less difficult for a petitioner to show group mistreatment resulting from unjust prison regulations or a general pattern of misbehavior on the part of prison authorities than to establish that he was singled out for mistreatment. Thus, in Johnson v. Dye, ${ }^{112}$ in which habeas corpus was used to challenge extradition, the petitioner, an escapee from a Georgia

107 The noninterference dogma is usually employed in addition to other grounds which are more particularly related to the remedial technique employed by the prisoner. See, e.g., Custis v. Jacques, 130 F. Supp. 920 (W.D. Mich. 1954); Commonwealth ex rel. Smith v. Banmiller, 194 Pa. Super. 566, 168 A.2d 793 (1961). Success for the prisoner is more promising under Civil Rights Act. See notes 133-39 infra and accompanying text.

108 See, e.g., United States ex rel. Bongiorno v. Ragen, 54 F. Supp. 973, 978 (N.D. Ill. 1944), aff'd, 146 F.2d 349 (7th Cir.), cert. denied, 325 U..S. 865 (1945), where the court said:

There is no evidence that the letter [addressed to the court] was or was not

transmitted. The docket of the Supreme Court is silent in respect thereof. The letter may or may not have been presented to the court and may or may not have been considered by it. While the court is in grave doubt, it does not feel that it can, on these facts, hold that there was a denial of the equal protection of the laws.

The court did not attempt to answer the unanswerable: How could the petitioner possibly meet this burden?

109 See Commonwealth ex rel. Thompson v. Day, 104 Pittsb. 317 (Pa. C.P.), aff'd, 182 Pa. Super. 644, 128 A.2d 133 (1956), cert. denied, 355 U.S. 843 (1957). In Sewell v. Pegelow, 291 F.2d 196 (4th Cir. 1961), the attorney for the appellants filed an appendix to their brief containing the names of twenty-two imprisoned Black Muslims who were willing to testify as to their mistreatment. Appendix to Appellant's Brief, pp. 5-6.

110 See Note, 59 Yale L.J. 800, 808 (1950).

111 Thus, for example, the courts should give the greatest possible latitude in their interpretation of petitioner's complaints and appeals. Cf. United States ex rel. Atterbury v. Ragen, 237 F.2d 953, 957 (7th Cir. 1956) (concurring opinion), cert. denied, 353 U.S. 964 (1957); Whiting v. Seyfrit, 203 F.2d 773, 774 (7th Cir. 1953); Allen v. Corsano, 56 F. Supp. 169, 170 (D. Del. 1944). (1949).

112175 F.2d 250 (3d Cir.), rev'd per curiam on other grounds, 338 U.S. 864 
chain gang, successfully established that he had been the victim of cruel and unusual punishment. Proof of mistreatment was made by the testimony of petitioner and other escapees, and by articles from magazines of national circulation ${ }^{113}$ which tended to establish "that it was the custom of the Georgia authorities to treat chain gang prisoners with persistent and deliberate brutality ... [and] that Negro prisoners were treated with a greater degree of brutality than white prisoners . . . ."114 In deciding that the alleged mistreatment had been established, the court was influenced by the fact that the state of Georgia offered no testimony whatsoever in contradiction to that given by the appellant's witnesses. ${ }^{115}$ Ironically, even this case so illustrative of the extraordinary circumstances necessary to establish physical mistreatment was ultimately reversed on other grounds. ${ }^{116}$ Moreover, since Johnson involved a prisoner who was no longer in the hands of the authorities who had allegedly mistreated him, it furnishes little hope for prisoners less favorably situated.117

The problems involved in the vindication of the right to be free from inhumane treatment are different, at least in degree, from those relating to other prisoner rights. Although this right has long been recognized, redress has been hampered by many of the difficulties which always face the aggrieved prisoner but which are heightened in connection with mistreatment. Not the least of these difficulties has been the reluctance of the courts to enter this particularly complex area where the line between discipline and brutality may be shadowy indeed; an area where vengeance and fear on all sides may seriously hinder the search for truth and the implementation of any remedy. Perhaps the withering of the noninter-

113 These articles were considered proper for consideration because they had been used by witnesses as a basis of comparison for conditions in Georgia prisons personally known to them. Id. at 253 .

114 Ibid.

115 Id. at 255-56.

116338 U.S. 864 (1949) (per curiam).

117 Another way in which prisoners have sought to establish mistreatment which might avoid the problems of the general run of such cases is by allegations of a denial of necessary medical treatment. Although the denial of medical treatment needed by a prisoner might at times be thought to rise to the level of cruel and unusual punishment, such allegations have met with little success. See, e.g., Snow v. Roche, 143 F.2d 718 (9th Cir.), cert. denied, 323 U.S. 788 (1944); Sarshik v. Sanford, 142 F.2d 676 (5th Cir. 1944) (per curiam); Feyerchak v. Hiatt, 7 F.R.D. 726 (M.D. Pa. 1948); State ex rel. Baldwin v. Superintendent, 192 Md. 712, 63 A.2d 323 (1949) (per curiam); Commonwealth ex rel. Rogers v. Claudy, 170 Pa. Super. 639, 90 A.2d 382 (1952) (per curiam). In Coleman v. Johnston, 247 F.2d 273 (7th Cir. 1957), petitioner brought suit under the Civil Rights Act alleging that while unlawfully detained without charge he was denied desperately needed medical attention, and that this denial resulted in the necessity of having his leg amputated. The district court dismissed the complaint on the theory that no deprivation of a constitutional right had been alleged. The court of appeals reversed, holding that the allegations were at least sufficient to prevent summary dismissal of the case. It is not possible to be sure that the court had endorsed the view that in extreme cases there may be a constitutional right to medical treatment. Only if this was in fact the meaning of the court's decision, and if-extrapolating one step further-another court would extend this right to a validly incarcerated prisoner, could Coleman represent the beginning of a shift from the many cases which uniformly have refused relief where denial of medical treatment had been alleged. 
ference doctrine with respect to other prisoner rights may encourage the courts to a somewhat more sympathetic attitude and more vigorous action in this area.

\section{REMEDIES}

\section{A. Habeas Corpus ${ }^{118}$}

Habeas corpus has been the device most commonly employed by prisoners seeking relief from denials of constitutional rights. ${ }^{119}$ However, when a petitioner, admitting the validity of his imprisonment, attempts by means of a habeas corpus petition to attack the manner in which he is being held, he finds even greater difficulties than those normally associated with this writ.120 In the overwhelming majority of cases the writ has been refused unless the prisoner would be entitled to an absolute release. These decisions are generally grounded on the judiciary's familiar reluctance to interfere with prison administration 121 or on an inherent limitation of the writ itself. ${ }^{122}$ It is quite understandable that courts are not anxious to interfere with prison administration when the time is not yet ripe for action. For example, it is unnecessary for the court to examine the legality of part of a criminal sentence where relief is presently unavailable since the prisoner is still serving the admittedly valid part of his sentence. ${ }^{123}$ This argument, however, is not present where a condi-

118 Although habeas corpus is the most commonly used of the traditional remedies in cases of alleged mistreatment of prisoners, several other common-law and equitable remedies have been used-or their use sought-in this area. Among these are injunctions, see Piccoli v. Board of Trustees, 87 F. Supp. 672 (D.N.H. 1949) ; mandamus, see Oregon ex rel. Sherwood v. Gladden, 240 F.2d 910 (9th Cir. 1957); statutory remedies in the nature of mandamus, see Brown v. McGinnis, 10 N.Y.2d 531, 180 N.E.2d 791, 225 N.Y.S.2d 497 (1962); and common-law certiorari (which has been used in New Jersey to permit review of parole board decisions), see Urbaniak, Rights of Prisoners in Confinement, 8 CRIME \& DELINQUENCY 121 (1962). Although these remedies may on occasion permit the prisoner to avoid some of the problems inherent in the use of habeas corpus, they are not of sufficiently general availability to replace habeas corpus as the normal remedy in this area. Compare text accompanying notes $133-39$ infra.

119 See generally Note, 33 Neb. L. REv. 434 (1954); Note, 59 YALE L.J. 800 (1950) ; 2 J. Pub. L. 181-85 (1953).

${ }^{120}$ An examination of the many problems involved in any habeas corpus proceeding is beyond the scope of this Note. See generally Reitz, Federal Habeas Corpus: Impact of An Abortive State Proceeding, 74 HARv. L. REv. 1315 (1961); Reitz, Federal Habeas Corpus: Postconviction Remedy For State Prisoners, 108 U. PA. L. REv. 461 (1960). Rather this Note is concerned only with the peculiar problem created by the fact that the prisoner admits that he is validly committed and objects only to the manner of his confinement.

121 See, e.g., Williams v. Steele, 194 F.2d 32 (8th Cir.), cert. denied, 344 U.S. 822 (1952); Taylor v. United States, 179 F.2d 640, 643 (9th Cir.), cert. denied, 339 U.S. 988 (1950); Edmondson v. Warden, 194 Md. 707, 69 A.2d 919 (1949).

122 See, e.g., Ex parte Hull, 312 U.S. 546 (1941); McNally v. Hill, 293 U.S. 131, 136-37 (1934); Commonwealth ex rel. Biglow v. Ashe, 348 Pa. 409, 35 A.2d 340 (1944) ; Commonwealth ex rel. Lieberman v. Burke, $158 \mathrm{~Pa}$. Super. 207, 44 A.2d 597 (1945); United States ex rel. Westbrook v. Randolph, 259 F.2d 215, 220 (7th Cir. 1958) (dissenting opinion).

123 See McNally v. Hill, supra note 122 , at 135 ; United States ex rel. Touhy v. Ragen, 224 F.2d 611, 613 (7th Cir. 1955), cert. denied, 350 U.S. 983 (1956); Sturm v. McGrath, 177 F.2d 472 (10 Cir. 1949). 
tional order ${ }^{124}$ might be used to investigate the allegations, grant the writ if proper, and remand the prisoner with directions for the correction of the unconstitutional treatment of a prisoner. Nevertheless, the vast majority of the courts have not recognized the possibility of a conditional order and have refused to use the writ to grant relief in such situations, assuming that habeas corpus may only be used where the remedy is absolute release. ${ }^{125}$ Yet even under this view if the mistreatment is sufficiently extreme the writ will be employed. ${ }^{126}$ In Johnson v. Dye, ${ }^{127}$ the petitioner, who had fled to Pennsylvania from a Georgia chain gang, was initially successful in a federal habeas corpus proceeding thereby preventing his extradition. The court, deeply impressed by the inhumane treatment that the petitioner had received, decided that a federal court was obliged to set him free since Georgia had "failed signally in its duty as one of the sovereign States of the United States to treat a convict with decency and humanity." 128 Judge O'Connell, concurring, expressed serious doubts as to whether past infringement of Johnson's constitutional rights would of itself entitle him to absolute release. However, recognizing that Johnson would face grave danger-and possible death-if extradited, he decided that it was preferable "that a potentially dangerous individual be set free than the least degree of an impairment of an individual's basic constitutional rights be permitted." 128

Not all courts feel themselves limited to the traditional view of habeas corpus. In Coffin v. Reichard, ${ }^{130}$ the court of appeals rejected this limitation on the federal writ as serving no real purpose. The court expressed the view that "any unlawful restraint of personal liberty may be inquired into on habeas corpus. . . . This rule applies although a person is in lawful custody. His conviction and incarceration deprive him only of such liberties as the law has ordained he shall suffer for his transgressions." 131 The court then concluded that the remedy in a habeas corpus proceeding is not limited to a simple remand or discharge but also may include a remand with directions that a prisoner's rights be respected or an order transferring the prisoner to another institution. Under this reasoning,

124 For an interesting solution by a court that believed that habeas corpus should be used only for complete release, see Medley, Petitioner, 134 U.S. 160, 174 (1890). In this case the Court "absolutely released" a convicted murderer unconstitutionally being detained in solitary confinement, but ordered that the attorneygeneral of the state should be notified of the precise time of the release so that the prisoner might promptly be rearrested.

125 See cases cited notes 121-22 supra.

126 Johnson v. Dye, 175 F.2d 250 (3d Cir.), rev'd per curiam on other gronthds, 338 U.S. 864 (1949); Commonwealth ex rel. Thompson v. Day, $182 \mathrm{~Pa}$. Super. 644, 648,128 A.2d 133, 136 (1956), cert. denied, 355 U.S. 843 (1957) (dictum).

127175 F.2d 250 (3d Cir.), reo'd per curram on other grounds, 338 U.S. 864 (1949).

128 Id. at 256.

129 Id. at 257-58. The Supreme Court's reversal, 338 U.S. 864 (1949) (per curiam) apparently rested on the grounds that exhaustion of state remedies, see $E x$ parte Hawk, 321 U.S. 114 (1943), is also required where habeas corpus issued to attack an extradition proceeding.

130143 F.2d 443 (6th Cir. 1944).

131 Id. at 445. 
habeas corpus becomes an adequate means for the review of alleged deprivations of civil rights of prisoners. Nevertheless, only a small minority of courts ${ }^{132}$ have reached the Coffin conclusion.

\section{B. The Civil Rights Act}

Absent a broad reading of habeas corpus, the most effective device for remedying violations of rights of state prisoners appears to be provided by the federal Civil Rights Act, ${ }^{133}$ which provides that any person who under color of law or custom, deprives any person under the jurisdiction of the United States of his constitutional or legal rights "shall be liable to the party injured in an action at law, suit in equity, or other proper proceeding for redress." 134 The act has been held applicable to prisoners. ${ }^{135}$ And it should not be difficult to show that prison authorities acted under color of state authority; not only is the act applicable to the enforcement of prison regulations, ${ }^{136}$ but it may be applied to actions in violation of state law which are carried out under "pretense of law." 137 Thus the greatest difficulty facing the prisoner who can establish the fact of mistreatment is that of showing that a federal right has been violated. For relief under this act-as under habeas corpus-requires the courts to determine what rights a prisoner possesses, ${ }^{138}$ a difficult task but one which the courts have shown an increasing willingness to undertake. ${ }^{130}$

M.W.S.

132 See United States ex rel. Westbrook v. Randolph, 259 F.2d 215 (7th Cir. 1958) ; In re Ferguson, 55 Cal. 2d 663, 361 P.2d 417, 12 Cal. Rptr. 753 (1961); In re Rider, 50 Cal. App. 797, 195 Pac. 965 (1920) ; People ex rel. Brown v. Johnston, 9 N.Y.2d 482, 215 N.Y.S.2d 44, 174 N.E.2d 725 (1961).

133 Rev. Stat. $\$ 1977-91$ (1875), 42 U.S.C. $\$ 1981-95$ (1958) ; see 2 J. Pub. L. $181,185(1953)$.

134 Rev. STAt. \$ 1979 (1875), 42 U.S.C. \$ 1983 (1958). The statute is not applicable to federal law enforcement officials, Gregoire v. Biddle, 177 F.2d 579, 581 (2d Cir. 1949), cert. denied, 339 U.S. 949 (1950) ; Swanson v. Willis, 114 F. Supp. 434 (D. Alaska 1953), aff'd per curiam, 220 F.2d 440 (9th Cir. 1955), but an action in trespass will lie against such officials when they act outside the scope of their authority, Cooper v. O'Connor, 99 F.2d 135, $139-40$ (D.C. Cir), cert. denied, 305 U.S. 643 (1938).

135 See Sewell v. Pegelow, 291 F.2d 196, 198 (4th Cir. 1961) ; Siegel v. Ragen, 88 F. Supp. 996, 998 (N.D. Il1. 1949), aff'd, 180 F.2d 785 (7th Cir.), cert. denied, 339 U.S. 990 (1950); Gordon v. Garrson, 77 F. Supp. 477 (E.D. I11. 1948).

136 Siegel v. Ragen, supra note 135, at 998.

137 United States v. Jones, 207 F.2d 785, 786-87 (5th Cir. 1953).

138 See Siegel v. Ragen, 88 F. Supp. 996, 999 (N.D. Ill. 1949), aff'd, 180 F.2d 785 (7th Cir.), cert. denied, 339 U.S. 990 (1950).

139 For recent cases arising under this act, see Pierce v. La Vallee, 293 F.2d 233

(2d Cir. 1961) ; Sewell v. Pegelow, 291 F.2d 196 (4th Cir. 1961) ; Bailleaux v. Holmes,

177 F. Supp. 361 (D. Ore. 1959), rev'd sub nom. Hatfield v. Bailleaux, 290 F.2d 632 (9th Cir.), cert. denied, 368 U.S. 862 (1961). Manifestly not all "mistreatments" by prison authorities will amount to a denial of a federal right. Compare Gordon v. Garrson, 77 F. Supp. 477 (E.D. I11. 1948), with Siegel v. Ragen, supra note 138. In the past courts have been hesitant to grant injunctive relief because of the fear that subsequent contempt proceedings might unduly hamper prison administration. It has been suggested that the alternative relief of damages available under the act would obviate this difficulty. See Note, 59 Y ALE L.J. 800,808 (1950); 2 J. Pú. L. 181, 186 (1953). 